\title{
OUTSIDE THE SMALL MEXICAN MARKET
}

A memory made itself out of stone

At the spinning of winter

Awakening in the sound of a bird

That would not fly

From the carcass it loved.

Outside the mercadito

Whispered alive I kept appearing

Until I became unreal

In the darkness of a bird

That would not fly

From the carcass of its devotion.

In the grace of the prehistoric

A line of monks

Held themselves along a white wall

In their tired ratios.

They had forgotten everything

In order to find a voice

For the carcass they worshipped

Out of stone in the spinning of winter. 